\title{
Social studies students' knowledge, attitude and practice of concepts of sustainable development in Ondo City, Nigeria
}

\section{Omoniyi Timilehin Olayinka}

Department of Arts and Social Sciences Education,

University of Ibadan, Ibadan, Nigeria

timmylayinka@gmail.com

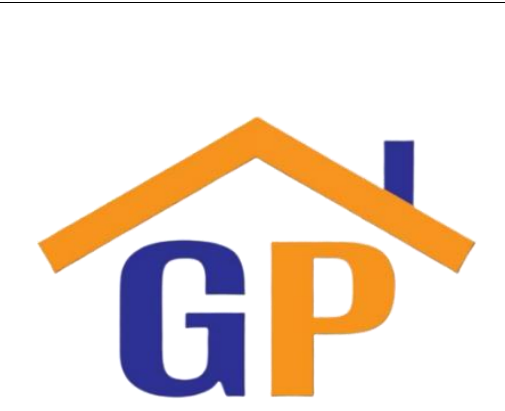

Article History

Received on 22 August 2019

$1^{\text {st }}$ Revision on 10 February 2020

$2^{\text {nd }}$ Revision on 10 March 2020

$3^{\text {rd }}$ Revision on 16 March 2020

$4^{\text {th }}$ Revision on 7 April 2020

$5^{\text {th }}$ Revision on 1 May 2020

Accepted on 4 May 2020

\begin{abstract}
Purpose: The study investigates Social Studies' students' knowledge, attitude, and practices of concepts of sustainable development in selected junior secondary school in Ondo city, Nigeria.
\end{abstract}

Research Methodology: The survey was conducted involving five hundred (540) students from ten (18) junior secondary schools. A self-constructed questionnaire titled 'Social studies' students knowledge, attitude, and practices of concepts of sustainable development in selected junior secondary school in Ondo state QSSSKAPCSD Cronbach alpha Reliability co-efficient of; KSDC: 0.70; PSDC: 0.73, and ASDC: 0.71 respectively was used. Three research questions were answered using simple percentage, mean (x) and standard deviation.

Result: The result shows Social Studies' students' level of knowledge, attitude and practices of sustainable development concepts is at an appreciable high level. The study recommended full implementation of various UNESCO's plan on sustainable development goals by all countries in the world.

Limitation: Sample size and area of coverage was the limitation of the study and this was due to the constraint of time and finance. Further studies should carry out an inferential statistics to analyse the variables.

Contribution: The study assessed students' level of knowledge, attitude and practices of sustainable development concepts in Social Studies.

Keywords: Sustainable development, Knowledge, Attitude, Practice

How to cite: Olayinka, O. T. (2020). Social studies students' knowledge, attitude and practice of concepts of sustainable development in Ondo City, Nigeria. International Journal of Financial, Accounting, and Management, 1(4), 221-233.

\section{Introduction}

The most populous black nation is bedeviled by continuous exhaustion of natural resources which is followed by low socio-economic and demographic growth, Nigeria as a nation is passing through the stage of political stress, economic recession, social crises and even environmental degradation. The side effect of which are in the prevalent bribery and corruption, unemployment, 
robbery, drug abuse and lack of patriotism, volcanic eruptions, enormous population pressure, built up of "greenhouse gases" (global warming), ozone layer depletion, oceanic despoliation (and loss of species), deforestation and loss of biodiversity, energy intensive agricultural system, over-use of pesticides (and species loss) among others (Bartosh, 2003 and De Lavega, 2004). The planet remains the same in size and circumference. The Earth is 25,000 miles in circumference, 4.5 billion by 1850 , from 1850 to 1987 5billion (Ogueri, 2004). Population explosion in less developed and developing countries is straining the already scare resources. Intensive agriculture practiced to provide food damages the environment through use of chemical fertilizer, pesticides and insectides.

There has been geometric growth of population and poverty in the country which is reaching unsustainable level in terms of resources like water, fuel and food. In the same vein, Wilkinson, Smith, Joffe and Haines (2007) reported that there have been growing realization that human beings activities are having major and intentional long-term adverse effect in the environment at a global, particularly the description of the biosphere's life support systems. Robinson (2013) espoused that "global capitalist system creates a treadmill of production because of its inherent need to build ever expanding profit; this treadmill necessitates creating an increasing demand for products obtaining natural resources at minimal cost and manufacturing products as quickly, as cheaply as possible no matter the long term environmental consequences". There has been tremendous pressure on mother earth and its environment.

The transformation is taken shapes at a geometric progression as evident in several human activities such as in industrialization, international trade, massive mechanized agriculture, bilateral and multilateral business investment and interest, food and energy production, urbanisation among others are changing the cause of earth system at large scale. Every countries and societies are industrializing at a very high pace without considering the effect on humanity and eco system. This invariably lead to destruction of the "earth immune system", threatens the biodiversity, declines natural resources, land unsuitability, tropical forest depleted and oceans habitats dies at will. In the long run, there is large scale degradation human being suffers from the effects. However, sustainable development can be seen in economic, social, and environmental protection/conservation sustainable development. Hence, the study assessed some sustainable development concepts in tandem with social studies students' knowledge, attitude and practices.

\section{Statement of problem}

Environmentally sustainable society meets the current needs of its people for food, air, clean water, shelter and other basic resources without compromising the ability of future generation to meet their needs. There have been numbers of studies on natural resource depletion and adverse impacts of environmental degradation and its impact on the lives of many which undermine the ability of all countries to achieve sustainable development. Presently, there is increase in global temperature, sea level rise, ocean acidification and other climate change which are seriously affecting coastal areas and low-lying coastal countries, including many least developed countries and small islands developing states. The survival of many societies, and of the biological support systems of the planet, is at risk. Therefore, it is against this background that there is need for more investigative work to assess junior secondary school students' knowledge of, attitude to and practice of sustainable development concepts in Ondo city is conscious of his/her environment and how he/she cares for it.

\section{Objectives of the study}

1. To assess the level of Social studies students' knowledge of sustainable development concepts in Ondo state

2. To ascertain Social studies students' attitude to sustainable development concepts. 
3. To investigate Social studies students' practice of sustainable development concepts.

Conceptual review

Sustainable development

According to Ogueri (2004), environment as the terrestrial natural sphere which inhabits people, plants and animals. It entails various living and non-living organisms from all sources of all lives for animals, plants and human beings. It is called bio-diversity housing acquatic, terrestrial, marine and other complex unseen or undiscovered ecosystems. Oyeshola (2008) viewed it as an embodiment of resources that are made available by Supreme Being for the survival all inhabitants of the earth surface. Based on this conferment on mankind, there is alarming pressure on the biodiversity, as such these resources are no longer sustainable for human being. Sustainability can be viewed freedom from want, fear and the ability of oncoming generation to maintain and sustain the planet earth without wreaking havoc on it. These are the main global challenges. The ultimate goals of sustainability is the capacity and capability to feed, nurture, inhabits and educate current and succeeding generations on how to grow and conserve the natural provisions and life support system of the earth, thereby reducing the high rate of pressure chaos and confusion. Hanway (1990) remarked that sustainable development is satisfying the needs, yearnings and aspiration of the human race both now and in the future without compromising required standards. He also added that there is need for earth's sustenance and maintenance of the entire bio-diversities within ecosystems through stringent measures to protect, control and promote ethical conducts and behaviour to the environment. The quality of the environment is the quality of mankind. The Earth Charter, (2000) laid credence to balancing the planet earth through respect for the environment, fulfilling hygienic conditions, curtailing excesses and promoting ecosystem unwritten rules. There is also the need for waste reduction, energy saving, ideal consumption, clean break from other development strategies. Succinctly, there is need to combine powerful element of economic management, protection and sound healthy living to ensure the earth's biodiversity and over all ecosystem did not die.

Table 1: A Transition toward Sustainability

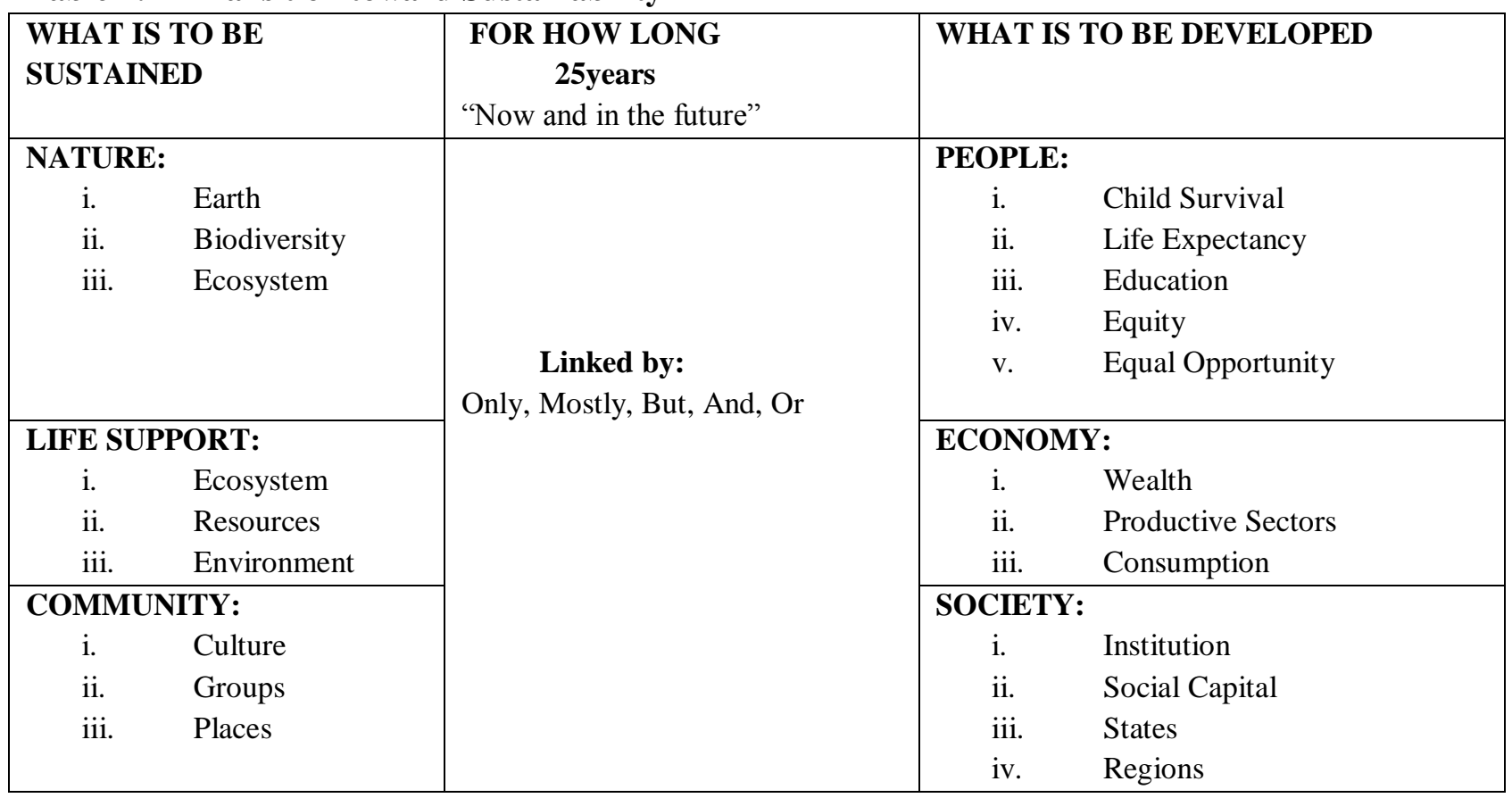


Source: U.S. National Research Council, Policy Division, Board on Sustainable Development, Our Common Journey: A Transition toward Sustainability (Washington, DC: National Academy Press, 1999).

\section{Literature review and hypotheses development}

\subsection{Studies on social studies' students' knowledge of sustainable development concepts}

Knowledge can be defines as the acquired information, facts and concepts through education, experience or investigation. It is the key resources to uphold sustainable advantage. Harts and Dowell (2011) advised that only the learning route will help solve environmental problems as well as help sustain it. submit that both form and informal learning opportunities and experiences will increase astronomically, people's knowledge of sustainability. In the same vein, a survey was conducted 23 third world countries, $83 \%$ of the total respondents fair ot high levels of concern for the environment. Majority of the respondents selected strongly possible response for seven of the eight environmental local and global issues and challenges examined which includes depletion of Ozone layer, climatic condition, water and air pollution among others. Lately, two studies, $52 \%$ of the respondents uphold that protecting the enforcement should be given utmost priority over and above creating employment opportunities, economic growth and diversification.

In their study, Harun, Hock and Othman (2011) affirmed in sabah, students from grade level 4 have high environmental knowledge for sustainability except for key concepts in which access current environmental issues in Malaysia such as carbon dioxide, climate change and other key challenges. Their attitude too is influenced by their level of knowledge of the environment. Adeolu, Enesi and Adeolu (2014) in their study on "assessment of secondary school students' knowledge, attitude and practices towards waste management in Ibadan, Oyo State, Nigeria" 358 students were used for the study out of the total 400 students surveyed. The result shows that students have moderate knowledge, attitude and practices of waste management in Ibadan. This can be said that students have average knowledge of, attitude to and practices of sustainable development concepts.

In his study, Ebong (1994), 192 students were sampled from Ja'afaru secondary school, Zaria, Nigeria. Questionnaire was used to elicit information on their knowledge of health the environment knowledge. Findings show that students' knowledge of environmental hygiene was high for all classes and students whose fathers had primary, secondary, or post-secondary education scored slightly higher than those whose fathers were illiterate. The critical analysis of environment sanitation observation in the school shows that there is absence of indoor plumbing, and pupils are usually accompanied to fetch water either pipe-borne or well water. Also, refuse disposal for homes and schools is through the local means of sewage and faeces disposal. This is usually dirty and ridiculously maintained. However with all these, pupils still have good environmental hygiene but with low opportunities to express, translate what they have learnt in carrying out health practices.

Findings from a study carried out at Kebangsaan University, Malaysia revealed students' knowledge and attitudes were very high but with moderate level of practices. Also based on gender, there was no significant difference in terms of knowledge, awareness, and practices. There is also significant difference in terms of attitudes male and female, as female had higher attitude to the environment than male child, while there is significant difference in knowledge of student bases on course of study. This implies that there is low level of knowledge compared to students from other course of study. Aminrad et al (2013) carried out a study to identify the nexus relationship among secondary school students' environmental knowledge, awareness and attitude. The survey was carried out with 470 respondents from Form 4 (16 years) in Kajang city, Selangor, Malaysia. Findings show that there is high level of awareness and knowledge as well as positive attitude. This could have been achieved as a result of agents of the society such as media effect, teachers, families, private reading, 
and school curriculum. These tend propel their sustainable development activities as well as increases environmental practices.

\subsection{Studies on social studies' students' attitude to sustainable development concepts}

Attitudes can be influenced by consumption choice behaviour, for example people's desires may be stronger than their beliefs and therefore have a negative attitude towards sustainability while still believing in sustainability as a cause. It has been recognized that to gain positive attitudes people need to learn and understand the subject at hand. Environmental attitude of young people appears to be crucial as they ultimately play a direct role in providing knowledge-based solutions to in coming environmental problems. School environmental programs, although addressed to students if properly channeled can also influence the environmental knowledge, attitude and behaviour of adults (parents, teachers and local community members) through the process of intergenerational influence (Gallagher et al., 2000). An individual attitude and concern for the environment or maintain environmental quality is also an important determinant of environmentally responsible behaviour which leads to sustainable development. Relating people's attitude to the environment, however, Bell and Rusell (2002) viewed environmental attitude as people's favourable or unfavourable feeling toward some features of the physical environment, or toward an issue which pertains to the physical environment. Attitude to sustainable development concepts can be viewed as the collection of beliefs, effect and behavioural intentions which a person holds regarding an environmentally related activities or issues. People with strong pro-environmental attitudes were found to be more likely to engage in proenvironmental behaviour, yet the relationship between attitudes and actions proved to be weak. Environmental attitudes are fundamentally important, widely discussed, frequently measured and poorly understood.

Meinhold and Malkus (2005) examined the relationships among adolescent's environmental behaviours in tandem with their knowledge, attitude and self-efficacy. 848 students were drawn from sound schools in the West Coast. The analysis was done using Hierarchical regression analyses. Findings indicate that pro-environmental attitudes predicted pro-environmental behaviours. Also, environmental knowledge was a significant moderator for the relationship between environmental attitude and behaviour, this was correct for male while skeptical for female. In her study, Zelezny et all (2000) remarked that women tends to have greatly significant environmental attitude than men across the 14 different countries involved in the study including Canada, Spain, Argentina. In another study, Zelezny and Bailey (2006) remarked that go green is one of the socialisation principles that known with women as they are closer and show more concern towards their environment due to their biospheric orientation. Weigel (1983) strongly affirmed that attitude and feelings on certain issues a person to behave in a consistent manner towards this purpose. Thus catching student young with the introduction of environmental and sustainability concepts will probably make them a better observer that is closer to the environment. Students tend to learn more if given the chance to get close to plants and other planetary elements as well as learn at their own pace. For instance, the types, shapes and importance of leaves as well as have full understanding of biodiversity, pollination, fertilization and other concepts. Learning these early in life have shown greater commitment to environmental responsibility, develop positive attitude and conserving behaviour.

\subsection{Studies on social studies' students' practice of sustainable development concepts}

Cleverdon, Pole, Banga, Weston and Tudor (2017) carried out a study in UK on the Engagement of students in Higher Education Institutions with the concepts of sustainability; A case study of the University of Northampton, England. They found that despite staunch students' support system with programmes likes Eco-Campus and other award schemes, students engagement is general low as regards sustainability. Boyes, $\underline{\text { Skamp and Stanisstreet (2008) }}$ remarked that $8.2 \%$ of students 
population do not recycle, 50\% claimed they were trying their best, while others were asking for support system to carry out eco-friendly activities. It was equally found out that these living within campus are less likely to recycle compare to those living off-campus. It is however noted that environmental benefits are responsive motivation for recycling. Thus there is low students' engagement in sustainable practices within the campus and across HEI in UK. In 2013, a survey was conducted in October/November in the University of Northampton, involving 577 students which were chosen at random. By 2014, a follow research was carried out involving 311 students chosen at random. Questionnaire was used to elicit information from participants. The following key questions were asked; what pro-environmental activities do you take part in whilst you are living in your termtime accommodation? Which activities consume the highest electricity usage? Can you list two sustainability initiatives employed on campus by the University of Northampton? What would encourage you to engage in a sustainability initiative? What are your views on the environmental sustainability initiatives at the University of Northampton?. From their responses, It was inferred that students' practice of sustainable development concepts was fairly moderate.

\section{Research methodology}

\subsection{Study area}

Ondo is a city found in Ondo state, Nigeria. It is located 7.09 latitude and 4.84 longitudes and it is situated at elevation 263 meters above sea level. Ondo City or Ode Ondo, situated in the Southwestern belt of the Nigerian rainforest, has a population of 257,005 making it the $2^{\text {nd }}$ biggest city in Ondo state. It operates on the WAT time zone, which means that it follows the same time zone as Akure. The location of Ondo in the middle of Nigeria's rain forest but with good access to the coast made the city a major transit point to northeast Yoruba land during the era of Yoruba civil war. Ondo City is the trade center for the surrounding region. Yam, cassava, grain, cotton and tobacco are grown and Aso-oke fabric serves as their famous traditional attire and is woven therein. Ondo City is the largest producer of cocoa products in the region.

\subsection{Design}

A descriptive quantitative research design was chosen and used to conduct the study on social studies students' knowledge, attitude, practice of concepts of sustainable development in selected junior secondary school in Ondo state. Purposive sampling method was utilized for selection of participants. Ondo state has eighteen (18) local government areas. There are 293 public junior secondary schools in the state. A purposive sampling technique was used to select one school from each local government areas making eighteen (18) junior secondary schools. Simple random sampling was used to select thirty (30) students from each of these schools making five hundred and forty (540) students altogether. The respondents were chosen at random from J.S.S 1-3, ten (10) students each from the levels. Data collected through the questionnaire survey were socio-economic attributes of the students and those pertaining to knowledge, attitude and practices of sustainability. All responses were analyzed using SPSS 21.0 software for statistical analysis. Descriptive statistics (means of frequency table distribution and percentages) were used.

\section{Results and discussion}

\subsection{Research questions}

1. To what degree/level is Social studies students' knowledge of sustainable development concepts?

Table 2: Responses on "The degree/level of Social studies students' knowledge of sustainable development concepts

\begin{tabular}{|l|l|l|}
\hline Knowledge of Sustainability/Sustainable development & Wrong & Right \\
\hline Have you heard of the term "sustainability" in your social studies class & 235 & 265 \\
\hline
\end{tabular}

2020 | International Journal of Financial, Accounting, and Management/ Vol 1 No 4, 221-233 


\begin{tabular}{|c|c|c|}
\hline & $47.0 \%$ & $53.0 \%$ \\
\hline The Sustainability refers to? & $\begin{array}{l}275 \\
55.0 \%\end{array}$ & $\begin{array}{l}225 \\
45.0 \%\end{array}$ \\
\hline Sustainable development involves? & $\begin{array}{l}209 \\
41.8 \%\end{array}$ & $\begin{array}{l}291 \\
58.2 \%\end{array}$ \\
\hline $\begin{array}{l}\text { Will care for the environment, environmental resources, mankind, tiling of environmental } \\
\text { floors and monitoring the flow of rivers and streams contribute to sustainability }\end{array}$ & $\begin{array}{l}47 \\
9.4 \%\end{array}$ & $\begin{array}{l}453 \\
90.6 \%\end{array}$ \\
\hline $\begin{array}{l}\text { We could make all our industrial process sustainable if we could abstain from healthy } \\
\text { living in the environment }\end{array}$ & $\begin{array}{l}7258 \\
51.6 \%\end{array}$ & $\begin{array}{l}242 \\
48.4 \%\end{array}$ \\
\hline Developed country assists undeveloped ones on economic sustainability development of & $\begin{array}{l}268 \\
53.6 \%\end{array}$ & $\begin{array}{l}232 \\
46.4 \%\end{array}$ \\
\hline $\begin{array}{l}\text { Some argue that globalization will have a negative impact because of its acceleration into } \\
\text { the technology world }\end{array}$ & $\begin{array}{l}219 \\
43.8 \%\end{array}$ & $\begin{array}{l}281 \\
56.2 \%\end{array}$ \\
\hline Waste reduction includes? & $\begin{array}{l}166 \\
33.2 \%\end{array}$ & $\begin{array}{l}334 \\
66.8 \%\end{array}$ \\
\hline $\begin{array}{l}\text { One of the specific methods to collect, treat and even reclaim waste include the following } \\
\text { except }\end{array}$ & $\begin{array}{l}259 \\
51.8 \%\end{array}$ & $\begin{array}{l}242 \\
48.2 \%\end{array}$ \\
\hline There are ways in which water consumption be reduced & $\begin{array}{l}168 \\
33.6 \%\end{array}$ & $\begin{array}{l}332 \\
66.4 \%\end{array}$ \\
\hline ........ Are natural hazard & $\begin{array}{l}173 \\
34.6 \%\end{array}$ & $\begin{array}{l}327 \\
65.4 \%\end{array}$ \\
\hline Global warming is a natural occurrence and not man-made & $\begin{array}{l}130 \\
26.0 \%\end{array}$ & $\begin{array}{l}370 \\
74.0 \%\end{array}$ \\
\hline Excess bush burning and fumigation has nothing to do with sustainable development & $\begin{array}{l}249 \\
49.8 \%\end{array}$ & $\begin{array}{l}251 \\
50.2 \%\end{array}$ \\
\hline $\begin{array}{l}\text { One of the global problems that are facing the world environment and are already } \\
\text { manifesting in Nigeria is ......... }\end{array}$ & $\begin{array}{l}222 \\
44.4 \%\end{array}$ & $\begin{array}{l}278 \\
55.6 \%\end{array}$ \\
\hline Agriculture plays a dominant role in the economies because? & $\begin{array}{l}304 \\
60.8 \%\end{array}$ & $\begin{array}{l}196 \\
39.2 \%\end{array}$ \\
\hline To make something new from something used or old . I will ...... my disposables & $\begin{array}{l}227 \\
45.4 \%\end{array}$ & $\begin{array}{l}273 \\
54 \%\end{array}$ \\
\hline $\begin{array}{l}\text { Environmental sustainability is achievable if the damage done to the planet earth is } \\
\text { reduced to the barest minimum }\end{array}$ & $\begin{array}{l}117 \\
23.4 \%\end{array}$ & $\begin{array}{l}383 \\
76.6 \%\end{array}$ \\
\hline $\begin{array}{l}\text { An important way to alter the perception that protecting the environment ins } \\
\text { incompatible with economic progress is through }\end{array}$ & $\begin{array}{l}67 \\
13.4 \%\end{array}$ & $\begin{array}{l}433 \\
86.6 \%\end{array}$ \\
\hline Building self-sufficiency is important for sustainability & $\begin{array}{l}121 \\
24.2 \%\end{array}$ & $\begin{array}{l}379 \\
75.8 \%\end{array}$ \\
\hline One key to reconnecting ourselves with nature except is to $\ldots . . .$. & $\begin{array}{l}236 \\
47.2 \%\end{array}$ & $\begin{array}{l}262 \\
52.8 \%\end{array}$ \\
\hline
\end{tabular}

It is observed that fifteen out of the twenty items had a higher degree/level of knowledge of sustainable development concept.

2. To what extent, is the attitude exhibits by Social studies students towards sustainable development concepts?

Table 3: Mean Responses on 'To what extent, is the attitude exhibits by Social studies students to sustainable development concepts?' 


\begin{tabular}{|c|c|c|c|c|c|c|}
\hline Items & SD & D & $\mathbf{A}$ & SA & Mean & S.D \\
\hline The earth is our mother, and we are all her children & $\begin{array}{l}26 \\
5.2 \%\end{array}$ & $\begin{array}{l}45 \\
9.0 \%\end{array}$ & $\begin{array}{l}167 \\
33.4 \%\end{array}$ & $\begin{array}{l}262 \\
52.4 \%\end{array}$ & 3.33 & .85 \\
\hline $\begin{array}{l}\text { I have personal duties and responsibility to make a } \\
\text { difference in the societal issues like in wellness }\end{array}$ & $\begin{array}{ll}20 \\
4.0 \%\end{array}$ & $\begin{array}{l}58 \\
11.6 \%\end{array}$ & $\begin{array}{l}161 \\
32.2 \%\end{array}$ & $\begin{array}{l}261 \\
52.2 \%\end{array}$ & 3.33 & .83 \\
\hline $\begin{array}{l}\text { Sustainable development is supposed to be "global in } \\
\text { nature" }\end{array}$ & $\begin{array}{l}34 \\
6.8 \%\end{array}$ & $\begin{array}{l}38 \\
7.6 \%\end{array}$ & $\begin{array}{l}168 \\
33.6 \%\end{array}$ & $\begin{array}{l}260 \\
52.0 \%\end{array}$ & 3.31 & .88 \\
\hline $\begin{array}{l}\text { Do you believe that planet earth is sustainable if current } \\
\text { patterns of natural resources use and consumption are } \\
\text { maintained }\end{array}$ & $\begin{array}{l}38 \\
7.6 \%\end{array}$ & $\begin{array}{l}51 \\
10.2 \%\end{array}$ & $\begin{array}{l}142 \\
24.4 \%\end{array}$ & $\begin{array}{l}269 \\
53.8 \%\end{array}$ & 3.28 & .93 \\
\hline I could do somewhat more to live sustainably & $\begin{array}{l}16 \\
3.2 \%\end{array}$ & $\begin{array}{l}62 \\
12.4 \%\end{array}$ & $\begin{array}{l}193 \\
38.6 \%\end{array}$ & $\begin{array}{l}229 \\
45.8 \%\end{array}$ & 3.27 & .80 \\
\hline I am interested in learning more about sustainability & $\begin{array}{ll}42 \\
8.4 \%\end{array}$ & $\begin{array}{l}55 \\
11.0 \%\end{array}$ & $\begin{array}{l}136 \\
27.2 \%\end{array}$ & $\begin{array}{l}267 \\
53.4 \%\end{array}$ & 3.26 & .96 \\
\hline $\begin{array}{l}\text { Excessive release of Carbon monoxide is not suitable } \\
\text { for humankind }\end{array}$ & $\begin{array}{l}48 \\
9.6 \%\end{array}$ & $\begin{array}{l}44 \\
8.8 \%\end{array}$ & $\begin{array}{l}164 \\
32.8 \%\end{array}$ & $\begin{array}{l}244 \\
48.8 \%\end{array}$ & 3.21 & .97 \\
\hline $\begin{array}{l}\text { I have personal duty to make a difference on } \\
\text { environmental issues like climate change }\end{array}$ & $\begin{array}{ll}35 \\
7.0 \%\end{array}$ & $\begin{array}{ll}43 \\
8.6 \%\end{array}$ & $\begin{array}{l}219 \\
43.8 \%\end{array}$ & $\begin{array}{l}203 \\
40.6 \%\end{array}$ & 3.18 & .86 \\
\hline $\begin{array}{l}\text { I have personal duty to make a difference on economic } \\
\text { issues like unemployment }\end{array}$ & $\begin{array}{l}25 \\
5.0 \%\end{array}$ & $\begin{array}{l}62 \\
12.4 \%\end{array}$ & $\begin{array}{l}216 \\
43.2 \%\end{array}$ & $\begin{array}{l}197 \\
39.4 \%\end{array}$ & 3.17 & .83 \\
\hline $\begin{array}{l}\text { There are adequate sewage and garbage disposal in our } \\
\text { facilities but are rarely used }\end{array}$ & $\begin{array}{l}52 \\
10.4 \%\end{array}$ & $\begin{array}{l}64 \\
12.8 \%\end{array}$ & $\begin{array}{l}183 \\
36.6 \%\end{array}$ & $\begin{array}{l}201 \\
40.2 \%\end{array}$ & 3.07 & 97 \\
\hline I believe the current way of life is sustainable & $\begin{array}{l}36 \\
7.2 \%\end{array}$ & $\begin{array}{l}69 \\
19.2 \%\end{array}$ & $\begin{array}{l}201 \\
40.2 \%\end{array}$ & $\begin{array}{l}167 \\
33.4 \%\end{array}$ & 3.00 & .90 \\
\hline $\begin{array}{l}\text { Sustainable development of living resources } \\
\text { (agriculture, aquaculture, fisheries, and forestry) is not } \\
\text { very important }\end{array}$ & $\begin{array}{l}110 \\
22.0 \%\end{array}$ & $\begin{array}{l}75 \\
15.0 \%\end{array}$ & $\begin{array}{l}141 \\
28.2 \%\end{array}$ & $\begin{array}{l}174 \\
34.8 \%\end{array}$ & 2.76 & .115 \\
\hline I'm not interested in living a sustainable lifestyle & $\begin{array}{l}280 \\
56.0 \%\end{array}$ & $\begin{array}{l}62 \\
12.4 \%\end{array}$ & $\begin{array}{l}62 \\
12.4 \%\end{array}$ & $\begin{array}{l}96 \\
19.2 \%\end{array}$ & 1.95 & 1.21 \\
\hline
\end{tabular}

Table three shows that majority of respondents that 'the earth is our mother, and we are all her children' $(\chi=3.33)$; and 'I have personal duties and responsibility to make a difference in the societal issues like in wellness' $(\chi=3.33)$. These were ranked first and second respectively among social studies students of junior secondary school. Conversely, 'Sustainable development of living resources (agriculture, aquaculture, fisheries, and forestry) is not very important' $(\chi=1.95)$ and 'I'm not interested in living a sustainable lifestyle' $(\chi=1.95)$ were ranked least. It has a grand mean 3.09. Test of norm was conducted with a calculated interval score of 17.3.

Test of norm on attitude exhibits by Social studies students to sustainable development concepts

\begin{tabular}{|l|l|l|}
\hline Interval & Total mean score & Remark \\
\hline $1-18$ & & Low attitudinal level \\
\hline $19-36$ & & Average attitudinal level \\
\hline $37-54$ & 40.12 & High attitudinal level \\
\hline
\end{tabular}

Thus, the overall mean score of the social studies scale is 40.12 which fall within the interval distribution of $37-54$ which is high concern/attitude to sustainable development. This simply means 
social studies students demonstrate a very strong and positive attitude to sustainable development in their environment.

3. Do Social studies students practice concepts of sustainable development?

Table 4: Mean Responses of Social studies students' practices of sustainable development concepts.

\begin{tabular}{|c|c|c|c|c|c|c|}
\hline Practice of Sustainable development concepts & $\mathrm{VO}$ & RO & $\mathrm{O}$ & $\mathrm{VO}$ & Mean & S.D \\
\hline I engage in environmental sanitation exercise & $\begin{array}{l}21 \\
4.2 \%\end{array}$ & $\begin{array}{l}56 \\
11.2 \%\end{array}$ & $\begin{array}{l}183 \\
36.6 \%\end{array}$ & $\begin{array}{l}240 \\
48.0 \%\end{array}$ & 3.28 & .83 \\
\hline $\begin{array}{l}\text { When leaving the house (room), I turn off the } \\
\text { unnecessary lights in order to contribute to energy } \\
\text { conservation }\end{array}$ & $\begin{array}{l}26 \\
5.2 \%\end{array}$ & $\begin{array}{l}65 \\
13.0 \%\end{array}$ & $\begin{array}{l}158 \\
31.6 \%\end{array}$ & $\begin{array}{l}251 \\
50.2 \%\end{array}$ & 3.27 & .88 \\
\hline I exhibit environmental responsible behaviour & $\begin{array}{l}28 \\
5.6 \%\end{array}$ & $\begin{array}{l}81 \\
16.2 \%\end{array}$ & $\begin{array}{l}136 \\
27.2 \%\end{array}$ & $\begin{array}{l}255 \\
51.0 \%\end{array}$ & 3.24 & .92 \\
\hline I do not protect the environment in the community & $\begin{array}{l}27 \\
5.4 \%\end{array}$ & $\begin{array}{l}69 \\
13.8 \%\end{array}$ & $\begin{array}{l}185 \\
37.0 \%\end{array}$ & $\begin{array}{l}219 \\
43.8 \%\end{array}$ & 3.19 & .87 \\
\hline I demonstrate interest in environmental issues & $\begin{array}{l}36 \\
7.2 \%\end{array}$ & $\begin{array}{l}60 \\
12.0 \%\end{array}$ & $\begin{array}{l}189 \\
37.8 \%\end{array}$ & $\begin{array}{l}215 \\
43.0 \%\end{array}$ & 3.17 & .90 \\
\hline $\begin{array}{l}\text { Watching documentaries on television and } \\
\text { listening to special programmes on radio about the } \\
\text { environment }\end{array}$ & $\begin{array}{l}43 \\
8.6 \%\end{array}$ & $\begin{array}{l}60 \\
12.0 \%\end{array}$ & $\begin{array}{l}178 \\
35.6 \%\end{array}$ & $\begin{array}{l}219 \\
43.8 \%\end{array}$ & 3.15 & .94 \\
\hline $\begin{array}{l}\text { I make sure our waste bin(both in school and } \\
\text { home) is properly disposed }\end{array}$ & $\begin{array}{l}31 \\
6.2 \%\end{array}$ & $\begin{array}{l}85 \\
17.0 \%\end{array}$ & $\begin{array}{l}85 \\
17.0 \%\end{array}$ & $\begin{array}{l}205 \\
41.0 \%\end{array}$ & 3.12 & .90 \\
\hline $\begin{array}{l}\text { I priotize saving the environment as one of the } \\
\text { most important issue }\end{array}$ & $\begin{array}{l}13 \\
2.6 \%\end{array}$ & $\begin{array}{l}71 \\
14.2 \%\end{array}$ & $\begin{array}{l}265 \\
53.0 \%\end{array}$ & $\begin{array}{l}151 \\
30.2 \%\end{array}$ & 3.11 & .73 \\
\hline $\begin{array}{l}\text { We recycle consumables, reduce waste and } \\
\text { practice energy reduction when possible }\end{array}$ & $\begin{array}{ll}35 \\
7.0 \%\end{array}$ & $\begin{array}{l}86 \\
17.2 \%\end{array}$ & $\begin{array}{l}166 \\
33.2 \%\end{array}$ & $\begin{array}{l}213 \\
42.6 \%\end{array}$ & 3.11 & .93 \\
\hline $\begin{array}{l}\text { I quickly inform relevant agencies } \\
\text { environmental issues }\end{array}$ & $\begin{array}{l}40 \\
8.0 \%\end{array}$ & $\begin{array}{l}87 \\
17.4 \%\end{array}$ & $\begin{array}{l}158 \\
31.6 \%\end{array}$ & $\begin{array}{l}215 \\
43.0 \%\end{array}$ & 3.10 & .96 \\
\hline I take direct action to defend the environment & $\begin{array}{l}22 \\
4.4 \%\end{array}$ & $\begin{array}{l}113 \\
22.6 \%\end{array}$ & $\begin{array}{l}182 \\
36.4 \%\end{array}$ & $\begin{array}{l}183 \\
36.6 \%\end{array}$ & 3.05 & .88 \\
\hline $\begin{array}{l}\text { I pick refuse from the floor to protect the } \\
\text { environment }\end{array}$ & $\begin{array}{l}49 \\
9.8 \%\end{array}$ & $\begin{array}{l}70 \\
14.0 \%\end{array}$ & $\begin{array}{l}187 \\
37.4 \%\end{array}$ & $\begin{array}{l}194 \\
38.8 \%\end{array}$ & 3.05 & .96 \\
\hline $\begin{array}{l}\text { I am willing to make small commitment in form of } \\
\text { environmental levy as part of my school fees to } \\
\text { protect the environment }\end{array}$ & $\begin{array}{l}73 \\
14.6 \\
\%\end{array}$ & $\begin{array}{l}60 \\
12.0 \%\end{array}$ & $\begin{array}{l}150 \\
30.0 \%\end{array}$ & $\begin{array}{l}217 \\
43.4 \%\end{array}$ & 3.02 & 1.07 \\
\hline $\begin{array}{l}\text { I keep the garbage or waste material until I can } \\
\text { find a waste bin }\end{array}$ & $\begin{array}{l}35 \\
7.0 \%\end{array}$ & $\begin{array}{l}118 \\
23.6 \%\end{array}$ & $\begin{array}{l}147 \\
29.4 \%\end{array}$ & $\begin{array}{l}200 \\
40.0 \%\end{array}$ & 3.02 & .96 \\
\hline $\begin{array}{l}\text { I prevent the formation of waste by given the left } \\
\text { over to street animals }\end{array}$ & $\begin{array}{l}49 \\
9.8 \%\end{array}$ & $\begin{array}{l}101 \\
20.2 \%\end{array}$ & $\begin{array}{l}167 \\
33.4 \%\end{array}$ & $\begin{array}{l}183 \\
36.6 \%\end{array}$ & 2.97 & .98 \\
\hline $\begin{array}{l}\text { I share links relevant with nature and } \\
\text { environmental awareness on social media } \\
\text { (Facebook, 2go, Twitter, Whatsapp, Instagram and } \\
\text { LinkedIn etc.) }\end{array}$ & $\begin{array}{l}105 \\
21.0 \\
\%\end{array}$ & $\begin{array}{l}64 \\
12.8 \%\end{array}$ & $\begin{array}{l}148 \\
29.6 \%\end{array}$ & $\begin{array}{l}183 \\
36.6 \%\end{array}$ & 2.82 & 1.14 \\
\hline $\begin{array}{l}\text { I allocate time and put in effort to help the } \\
\text { protection of animals (wildlife) }\end{array}$ & $\begin{array}{l}117 \\
23.4 \\
\%\end{array}$ & $\begin{array}{l}80 \\
16.0 \%\end{array}$ & $\begin{array}{l}147 \\
29.4 \%\end{array}$ & $\begin{array}{l}156 \\
31.2 \%\end{array}$ & 2.68 & 1.14 \\
\hline
\end{tabular}


Table four shows that majority of the respondents affirmed that 'I engage in environmental sanitation exercise' $(\chi=3.28)$; and 'When leaving the house (room), I turn off the unnecessary lights in order to contribute to energy conservation' $(\chi=3.27)$. These were ranked first and second respectively among social studies students of junior secondary school. Conversely, I share links relevant with nature and environmental awareness on social media (Facebook, 2go, Twitter, Whatsapp, Instagram and LinkedIn etc.)' $(\chi=2.82)$; 'I allocate time and put in effort to help the protection of animals (wildlife)' $(\chi=2.68)$. Test of norm was conducted with an interval score of 22.66 .

Test of norm on Social studies students' practices of sustainable development concepts

\begin{tabular}{|l|l|l|}
\hline Interval & Total mean score & Remark \\
\hline $1-22$ & & Low \\
\hline $23-46$ & & Average \\
\hline $47-68$ & 52.35 & High \\
\hline
\end{tabular}

Thus, the overall mean score of the Social studies students' practices of sustainable development concepts scale is 52.35 which falls within the interval distribution of 47-68 which is high. Hence, the practice of sustainable development concepts is positive.

\subsection{Discussion of findings}

The result shows Social studies students' knowledge and practices of concepts of sustainable development is at an appreciable/moderate level. This study agrees with the research carried out by Ahmad, Noor and Ismail (2015). The study assessed the relationship between students' knowledge, attitude and practices of environment and effective communication of environmental messages. The study was conducted using 895 students from 16 higher institutions in Malaysia. It revealed that students have good knowledge of environmental knowledge but does not translate environment practices. Hence, there was a no relationship between students' attitude and sustainable environmental practices. This shows that attitude is may not be a good predictor for sustainable environment practices. The results show the complexities among the three variables.

Besar et al (2013) and Ahmad et al (2012) affirmed that there is high level of environmental knowledge and understanding among Malaysian youths. This is evident in the effort put in place by Malaysian government to checkmate citizens' excesses as well as policies and programmes in maintaining sustainable development. Also, the introduction of SD components in Malaysian educational system as well as the pro-active role of the countries' higher institution in champion=ing the course of sustainability as being practiced in USM and UKM (FOO 2013; UKM,2014, USM, 2014). The findings revealed that attitude has a direct link with knowledge of sustainable development concepts, while practice has an indirect link. In the same vein, "interest to learn more about sustainable environment" with $78.6 \%$ while "interest to join sustainable activities" with $68.9 \%$ " shows the lowest percentages compare to other items. These results may be so due to numerous factors such as a well planned and executed learning activities related to the environment which are communicated to the students. Indirectly, Stamm et al (2000) and Felix (2004) supported the importance of communicating environmental activities and messages to students.

Harun, Hock and Othman (2011) suggest both formal and informal learning opportunities help to advance citizens' knowledge levels about sustainability. It is likely that when engage in environmentally responsible projects, they begin to demonstrate pro-active measures towards such environment. The knowledge acquired can therefore influence their attitude to sustainability, this is because, their ability to understand and interpret contributes to pro-active measures and behaviour 
they will begin to exhibits. Hence, there is need to invest heavily in citizen's acquisition of environmental knowledge before they can begin to exhibit good environmental conduct. Robinson $\underline{(2013)}$ corroborates the findings above that a change in attitude is required to sustain the environment. Also, such changes will lead to clean wealth creation, development goals, motivations and alternative values. The Higher Education Academy (2017) funded a study on students' attitudes towards and skills for sustainable development. It was discovered that $80 \%$ of students involved in the study want their school authority to actively inculcate sustainable development concepts and practices into their learning content, while a total of $60 \%$ like to more about environmental sustainability. Another soft study was conducted for a fifth consecutive year in 2014 by the same body (HEA). The study updated the student's understanding attitude to and skills for sustainable development with 3,775 students from a first year and a 1,973 from a third year in the 2013/14 academic session. It was found that students' exhibit average knowledge of sustainable development but showed much interest in the incorporation of sustainable development concept in the curriculum. According to Orr (1992) asserts that ecological literacy entails the knowledge needed and necessary to comprehend interconnectedness and attitude toward caring towards the environment for the good of all inhabitantshuman, animal and plants. Hence, there is need for full knowledge, caring attitude and practical pretense which serves as the fundament factors needed for sustainable development.

\section{Conclusion}

Sustainable development is the situation which satisfies the need, yearnings and aspirations of the present generation without compromising the capability for the future ones. It entails creating a balance between human needs and want, doing this will curtail human excesses as well as promote staunch sustainable development. The need to fight degradation of the natural environment is on the increase as every effort must be geared towards combat human's exploitation and unnecessary exploration natural resources without trying to replace them. The choice of lifestyle, technology appropriation and institutional modification should be in tandem with the future needs of the next generation. Sustainability is always an integrated process with multiple loops and synergies. Though the level of knowledge, attitude and practice of sustainable development concepts was relatively high in secondary schools in Ondo state, yet environmental problems in Nigeria are becoming issues of concern. These identified environmental problems are caused by natural and as well as human factors, which calls for more attention in terms of high and quality level of knowledge and understanding, positive attitude, genuine concern, rapt awareness and committed daily practices for all and sundry. There is the need to enlighten the students and the populace by extension on sustainable development concepts. Based on this, it becomes apparently important that the aims of sustainable development must be considered by individuals, by companies, and on a planet-wide level.

\section{Recommendations}

i. There is need for full implementation of various UNESCO's plan on sustainable development goal by all countries in the world A systems approach to sustainability and sustainable Development.

ii. There is need for the re-introduction of environmental education into the school curriculum which will cater for developing a healthy, sustainable society.

iii. There is need for solid public campaigns, seminars, symposia and health talks to all and sundry most especially; students, parents, traders, farmers etc on the degradation of the environment, as this will avail them the opportunity to have proper knowledge of environmental disasters, waste management system and sound healthy living. 
iv. It is also recommended that environmental experts in collaboration with NGOs and other concerned bodies who have concern for environmental protection and sustainability should provide training that equip students with environmental knowledge, attitude, daily environmental practices and civic participatory behaviour which will, if properly marshaled, inculcate environmentally responsible behaviours in the students.

v. There is need for environmental knowledge through printed and electronic/social media on sustainable development concepts across the country which in turn increases good attitude and participatory behaviour in the wider Community.

\section{Limitation and study forward}

Sample size, area of coverage and the number of variables considered are limitations of this study. The sample comprised only five hundred and forty (540) students from Ondo city. The sample size and area of coverage was due to the constraint of time and finance.

\section{References}

Adeolu, A.T , Enesi D.O and Adeolu.M.O. (2014). Assessment of secondary school students' knowledge, attitude and practices towards waste management in Ibadan, Oyo state, Nigeria. Journal of Research in Environmental Science and Toxicology. 3(5) 66-73

Ahmad, A.L., Rahim, S.A., Pawanteh, L., Ahmad, F. (2012) The understanding of environmental citizenship among Malaysian youths: A study on perception and participation. Asian Social Science, 8(5), 85-92.

Ahmad, J.; Noor, S.M \& Ismail, N (2015) Investigating Students' Environmental Knowledge, Attitude, Practice and Communication. Asian Social Science; 11(16)

Aminrad Z, Zakariya, S.Z, Hadi A.S and Sakari, M (2013) Relationship Between Awareness, Knowledge and Attitudes Towards Environmental Education Among Secondary School Students in Malaysia. World Applied Sciences Journal 22 (9): 1326-1333,

Bartosh, O 2003 Environmental education: improving student achievement (Master's thesis, The Evergreen State College) Retrieved from www.hpoe.org/environmentalsustainability

Bell, R. G. \& Russell C (2002) Environmental Policy for Developing Countries. Issues in Science and Technology 18(3)

Besar, T. A., Hassan, M. S., Bolong, J., \& Abdullah, R. (2013). Exploring the levels of knowledge, attitudes and environment-friendly practices among young civil servants in Malaysia. Pertanika journals of social science \& humanities 21(21-38)

Cleverdon, L., Pole, S., Weston, R., Banga, S., \& Tudor, T. L. (2017). The Engagement of Students in Higher Education Institutions with the Concepts of Sustainability: A Case Study of the University of Northampton,

England. Resources, 6(1). https://doi.org/10.3390/resources6010003

De Lavega, Ernesto Lasso 2004 Awareness, knowledge, and attitude about environmental education: responses from environmental specialists, high school instructors, students, and parents (Doctoral thesis, College of Education at the University Central Florida, Orlando) Retrieved from http://library.ucf.edu

Ebong, R.D. (1994). Environmental health knowledge and practice survey among secondary school children in Zaria, Nigeria. Environmental Health Perspective.10(2)3-4.

Felix, A. (2004). Making youth voice a community principle. Youth Service Journal, 1(1), 1-13.

Foo, K. Y. (2013) A vision on the role of environmental higher education contributing to the sustainable development in Malaysia. Journal of cleaner production 61(6-12)

Gallagher J, Wheeler C, McDonough M, Namfa B (2000). Sustainable environmental education for a sustainable environment: lessons of Thailand for other nations. Journal of water air and soil Pollut, 123(1- 4): 489- 503. 
Hanway D.G (1990) Our common future-from one earth to one world, Journal of Soil and Water Conservation September, 45 (5) 510

Hart, S.L., Dowell, G. (2011), "A Natural-Resource-Based View of the firm: Fifteen years after". Journal of Management, 37(5): 1464-1479.

Harun, R. L; Hock, K and Othman, F (2011) Environmental Knowledge and Attitude among Students in SabahWorld Applied Sciences Journal 14 (Exploring Pathways to Sustainable Living in Malaysia: Solving the Current Environmental Issues): 83-87, 2011 ISSN 1818-4952

Meinhold, J.L., \& Malkus, A.J. (2005). Adolescent environmental behaviors: Can knowledge, attitudes, and self-efficacy make a difference? Environment and Behaviour, 37(4) 511- 532

National Academy Press, (1999) U.S. National Research Council, Policy Division, Board on Sustainable Development, Our Common Journey: A Transition toward Sustainability. Washington, DC

Ogueri A. C. (2004) The need for environmental education in secondary education level in Nigeria: problems and challenges (Master's thesis, Rosklide University, Denmark) Retrieved from

Orr, D. (1992). Ecological literacy: Education and the transition to a postmodern world. Albany, New York: State University of New York Press.

Oyeshola, D.O. (2008) Sustainable Development: Issues and challenges for Nigeria. Ibadan: Daily Graphics

Robinson J O (2013). Environmental Education and Sustainable Development in Nigeria: Breaking the missing link. International Journal of Education and research, 1(5),1-6

Skamp, K, Boyes, E \& Stanisstreet, M 2008, 'Australian secondary students' views about global warming: beliefs about actions, and willingness to act', paper presented to the 15th Australian Association for Environmental Education Conference, Darwin, NT, 9-13 Jul

Stamm, K. R., Clark, F., \& Eblacas, P. R. (2000). Mass communication and public understanding of environmental problems: the case of global warming. Public understanding of science, $\quad 9$, 219-237. http://dx.doi.org/10.1088/0963-6625/9/3/302

The Earth Charter. (2000). Retrieved April 30, 2019, from http:// www.earthcharterinaction.org/content/pages/Read-the-Charter. htmlPress.

The Higher Education Academy (2017) Assessment and Feedback in Higher Education: A Review of Literature for the Higher Education Academy". Retrieved https://research.acer.edu.au/higher_education/53

U.S. National Research Council, Policy Division, Board on Sustainable Development (1999) Our Common Journey: A Transition toward Sustainability (Washington, DC: National Academy Press) Retrieved from https://www.nap.edu/catalog/9690/our-common-journey-atransition-toward-sustainability

UKM. (2014). Institute for environment and development (LESTARI). Retrieved from http://www.ukm.my/ lestari/en/profil/

USM (2014) Centre for global sustainability study. Retrieved July 4, 2014, from http://cgss.usm.my/index.php/kedua/submenu

Weigel, R. H. (1983). Environmental attitudes and the prediction of behavior Environmental psychology: Directions and perspectives, 257-287.

Wilkinson P, Smith KR, Joffe M, Haines A. (2007) A global perspective on energy: health effects and injustices. Retrieved from DOI:10.1016/s0140-6736(07)61252-5

Zelezny, L., \& Bailey, M. (2006). A call for women to lead a different environmental movement. Organization \& environment, 19(1), 103-109. http://dx.doi.org/10.1177/1086026605285588

Zelezny, L., Chua, P. P., \& Aldrich, C. (2000). Elaborating on gender differences in environmentalism. Journal of Social Issues, 56, 443-457. 